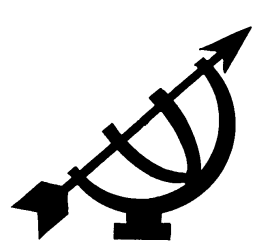

\title{
Die antitese tussen witboordjiemisdaad en sake-etiek
}

\author{
R.A. (Ronnie) Lotriet \\ Programbestuurder MBA-Opleiding \\ Potchefstroom Besigheidskool \\ Potchefstroomkampus \\ Noordwes-Universiteit \\ POTCHEFSTROOM \\ E-pos: Ronnie.Lotriet@nwu.ac.za
}

\section{Abstract \\ The antithesis between white-collar crime and business ethics}

Transparency International states that the scourge of whitecollar crime and corruption is endemic in both the developed and developing world. South Africa is no exception, as the perception prevails that not only have violent crimes increased in recent years, but that white-collar crimes are also escalating. Very little academic research on white-collar crime has been undertaken thus far.

Like the Postmodern Movement, the current technology-driven network economy has no foundational ethic, which creates the ideal situation for further fostering the seeming lack of shared values. But there is no reason to accept the imperative of the new order without challenge. Therefore, ethics education at management level has a fundamental role to play in the market operations of the 21st century. The article explores what is happening in practice at business school level and their focus worldwide on relevant training to address the needs of the dynamic market environment.

\section{Opsomming}

\section{Die antitese tussen witboordjiemisdaad en sake-etiek}

Transparancy International stel dit dat die toestand van witboordjiemisdaad en korrupsie endemies is in ontwikkelde en ontwikkelende lande. Suid-Afrika is geen uitsondering nie; trouens, die persepsie bestaan dat geweldsmisdaad die 
afgelope paar jaar toegeneem het tesame met witboordjiemisdaad wat ook hoogty vier. Tot dusver is baie beperkte akademiese navorsing oor witboordjiemisdaad gedoen.

Parallel met die Postmoderne Beweging het die huidige tegnologie-gedrewe netwerk-ekonomie geen fundamentele etiek nie, wat die ideale situasie laat onstaan vir 'n skynbare gebrek aan gedeelde waardes. Daar is egter geen rede om die nuwe orde lukraak te aanvaar sonder uitdagings nie. Daarom het etiekopleiding in die bestuurswese 'n fundamentele rol om te speel in die markbedrywighede van die 21e eeu. Die artikel ondersoek wat by sakeskole wêreldwyd gedoen word al dan nie ten opsigte van sake-etiek, om die behoeftes van die mark te voed.

\section{Inleiding}

Daar bestaan 'n daadwerklike interverwantskap tussen misdaad en die volkshuishouding. By die Wêreld Ekonomiese Forum het deelnemers verwys na Suid-Afrika se toenemende misdaadgolf (Hogg, 2007). Geweldsmisdade is een van die faktore wat beperkend inwerk op die vereiste $6 \%$ ekonomiese groei wat volgens die regering se versnelde groeistrategie ("Asgisa": Accelerated and Shared Growth Initiatives) benodig word (Botha, 2007:10). Indien die baie lae rapporteringskoers, die indirekte effek en aanname van 'n addisionele "donker syfer" vir misdaad boonop in ag geneem word, neem die omvang van misdaad in Suid-Afrika inderdaad krisisproporsies aan.

Die veralgemening dat meer werksgeleenthede Suid-Afrika se misdaadprobleme outomaties sal oplos, is verkeerd in soverre dit onder andere nie met witboordjiemisdade rekening hou nie. Navorsingsbevindings dui aan dat witboordjiemisdade, net soos geweldsmisdaad, bogemiddeld hoog en eskalerend is. Die kriminele aard van witboordjiemisdaad (ekonomiese misdaad) soos byvoorbeeld korporatiewe wangedrag ten opsigte van omgewingsaspekte, verbruikersgesondheid en veiligheidsregulasies is veel meer skadelik. Die ekonomiese koste verbonde aan witboordjiemisdaad oorskry die afgeleide waarde uit alle misdaad op straat by verre (Camerer, 1996).

Die meerderheid witboordjiemisdaadoortreders beklee bestuursposte (Ueckermann, 2007:1). Dit kan dus met reg bevraagteken word watter soort bestuursopleiding sakeskole regoor die wêreld aanbied. In hierdie verband noem Singer (1987) die volgende: 
We who run (...) business schools are concerned about how people behave in business, and our responsibility to influence positive ethical behaviour is considerable and urgent. We must teach not only the skills of management but also the principles of right and wrong.

Hierdie artikel plaas laasgenoemde saak in perspektief en fokus pertinent op die relevansie van sakeskole se formele graadopleiding (MBA), en ander sogenaamde uitvoerende bestuurskursusse.

\section{Die misdaad-potpoumi}

\subsection{Algemeen}

Die uitstaande kenmerk van misdaad in Suid-Afrika is nie net die omvang nie, maar ook die geweld daaraan verbonde: die moordkoers is van die hoogste ter wêreld (39,5 per 100000 - populasie in 2005/2006); met roof en verkragting wat meer as dubbel die koers in lande soos die VSA is, inaggenome die tendens van lae rapporteringskoerse (Honey, 2006:90). Oor die algemeen verteenwoordig die amptelike misdaadstatistiek minder as $10 \%$ van die werklike voorvalle wat plaasvind, en $51 \%$ van alle misdade wat nie gerapporteer word nie (Camerer, 1996). ' $n$ Kommerwekkende aspek is ook die feit dat misdaadstatistieke slegs volgens die prerogatief van die verantwoordelike minister mag plaasvind, wat 'n demper kan plaas op die eis vir deursigtigheid.

Die kostes van misdaad in Suid-Afrika is ongeveer dieselfde as in lande soos Brasilië, Rusland, Peru en die Filipyne. Die groot verskil met hierdie lande is dat in Suid-Afrika besighede self ' $n$ groter deel van die kostes van die direkte verlies aan omset en personeel dra, terwyl dit in die ander lande grotendeels in die vorm van voorkoming is (Honey, 2006:91). Voorkoming is merendeels in die vorm van sogenaamde "beskermingsgeld" aan georganiseerde misdaadsindikate. 'n Voorbeeld van die eskalerende kostes is dat privaatsekuriteitspersoneel in Suid-Afrika met $150 \%$ gegroei het vanaf 1997 tot 2005. In teenstelling met berigte deur die regering dat misdaad onder beheer is, het regeringsbesteding aan privaatsekuriteit in pogings om die toenemende misdaad die hoof te bied, met ongeveer $80 \%$ gedurende die afgelope twee jaar gestyg (Hartley, 2007:3). Die besteding in 2006 was R118 miljoen meer $(78,5 \%)$ as in 2005 , met die totaal oor die twee jare R450,5 miljoen. Dit bevestig dat Suid-Afrika midde-in 'n ernstige misdaadgolf vasgevang sit, met 18 uit 24 staatsdepartemente wat hulle bestedings dramaties verhoog het. 
'n Navorsingsverslag deur die Wêreldbank het bevind dat $30 \%$ van besighede in Suid-Afrika misdaad as 'n ernstige belemmering vir beleggings beskou - aansienlik méér as die gemiddeld vir ontwikkelende ekonomieë (Honey, 2006:90). Die eskalering in misdaad laat 'n land se ekonomiese kostes aansienlik styg: 'n korrelasie is gevind tussen hoë moordkoerse en die lae ekonomiese groei van areas soos stede - 'n 10\% styging in moorde veroorsaak dat dit 'n area se ekonomiese groei met 1,1\% oor 10 jaar laat daal.

\subsection{Die konsep van witboordjiemisdaad}

Die konsep van witboordjiemisdaad het nie 'n algemeen aanvaarde definisie nie. Pogings om 'n eenduidige beskrywing te vind, is reeds in 1939 opgeteken toe 'n Amerikaanse sosioloog Edwin Sutherland die konsep probeer beskryf het as: "a crime committed by a person of respectability and high social status in the course of his occupation" (Camerer, 1996). Die konsep is eerder 'n sambreelterm om na 'n reeks aktiwiteite te verwys soos verbruikersbedrog, verduisteringspraktyke, wanvoorstellings, belastingswendelary, binnehandel, effekte-oortredings, korrupsie, omkopery en gunsloonskemas (kickbacks), rekenaarbedrog en korporatiewe ongerymdhede soos met bedryfsveiligheids- en gesondheidsoortredings.

Witboordjiemisdaad is in wese ekonomiese misdaad wat, net soos geweldsmisdaad, endemiese afmetings aanneem - een komponent daarvan is korrupsie, wat jaarliks groei. In markterminologie word witboordjiemisdaad beskou as om in 'n ware bulmark te wees. 'n Mark beskryf die neiging en sentiment wat dit dryf - só beskou, is die mark vir veral witboordjiemisdaad in SA "bulgedrewe" (bullish), want sodanige markte neig om met toenemende "koopgedrag" gekenmerk te word in afwagting van verdere winsneming.

Die verliese wat gely word as gevolg van ekonomiese misdaad, word geskat om groter te wees as die land se Bruto Binnelandse Produk, wat teen markpryse vanaf 1999 se R813 683 miljoen na R1 726688 gestyg het (SARB, 2007; Camerer, 1996). Die meerderheid hiervan is korrupsie/bedrog en die res is misdade soos diefstal deur werknemers en oortredings van die meer as 50 statute wat deur die handelstakke gepolisieer word. Die impak daarvan is egter veel meer as net die kwantifisering in monetêre terme: korrupsie in 'n Staatsdepartement sal byvoorbeeld behoeftiges weerhou van dienslewering. Gevolglik het dit 'n oorspoeleffek na sowel sosiale as morele kostes. Dit word algemeen aanvaar dat dit in beginsel onmoontlik is om byvoorbeeld die vlakke van bedrog te kwantifiseer - die bekendmaking van misdaadstatistiek is gewoonlik 
baie breed en daar word nie tussen spesifieke oortredings binne die kategorie van ekonomiese misdaad of bedrog onderskei nie. Met die konseptualisering van die begrip moet egter wel onderskei word tussen die volgende:

- organisatoriese misdaad, wat uitgevoer word met die ondersteuning van die formele organisasie ten einde sy doelwitte te bevorder; en

- beroepsmisdaad, wat uitgevoer word deur individue of 'n groep individue wat eksklusief persoonlike gewin ten doel het (soos met die vermelde definisie deur die sosioloog hierbo bedoel word).

Navorsing onder 11200 uitvoerende korporatiewe beamptes in 125 lande het bevind dat Suid-Afrikaanse maatskappye die sesde plek behaal met betrekking tot omkopery in buitelandse transaksies (Malala, 2006:109). Navorsing deur die ouditeursfirma KPMG het bevind dat die profiel van die tipiese witboordjie-oortreder soos volg daar uitsien (Ueckermann, 2007:1):

- die meerderheid oortreders is mans;

- in $89 \%$ van die gevalle is ondernemings deur hulle eie werknemers benadeel;

- $86 \%$ van die oortreders is in bestuursposte (waarvan $60 \%$ deel is van die senior bestuur of direksies);

- $36 \%$ is werksaam vir tussen 2-5 jaar en 29\% tussen 6-10 jaar;

- die meeste is werksaam in finansies (36\%), of in bedryfs- en verkoopsafdelings; en

- in meer as $90 \%$ van die gevalle is oortreders betrokke by meer as een oortreding.

Alhoewel die indirekte invloed van ekonomiese misdade alle burgers van die land in slagoffers omskep, word hierdie tipe misdade nog minder as ander misdade gerapporteer - daar is bevind dat slegs $20 \%$ van respondente aangedui het dat hulle bedrogsake aan die polisie gerapporteer het (per implikasie word $80 \%$ van die bedrog dus nie gerapporteer nie) (Ueckermann, 2007:1). Ander verslae dui aan dat selfs soveel as $95 \%$ van sekere tipes ekonomiese misdade, soos omkopery, onopgespoor bly (Anon., 2006). Laasgenoemde dra by tot die gevolgtrekking dat hierdie misdaad betalend is. Die indirekte invloed is byvoorbeeld dat die stygende kostes verskuil bly 
in die hoër pryse van goedere en dienste wat na die verbruiker afgewentel word.

Voorts word 'n addisionele "donker syfer" aanvaar wat misdade soos gesteelde tjeks verteenwoordig waarvan sowel die slagoffer as die polisie onbewus is - dit vererger gevolglik die vermelde syfers. 'n Groot hoeveelheid bedrog word egter nie opgespoor nie byvoorbeeld die talle vals eise by lewensversekeraars ten opsigte van mediese toestande gedurende die stadium waarin polisse "geskryf" word (Cranston, 2006:57).

\section{3 Óók in die openbare sektor}

Sowel die openbare- as privaatsektore van die volkshuishouding word met witboordjiemisdaad geassosieer. Die hele Afrikakontinent is bogemiddeld verdag weens die omvang wat praktyke soos korrupsie aanneem. Daar word bereken dat Nigerië se leiers in die openbare sektor hulself verryk (korrupsie) het met ongeveer $\$ 380$ biljoen van die land se oliewelvaart sedert onafhanklikheidswording. Laasgenoemde is die ekwivalent van ongeveer twee-derdes van al die buitelandse hulp wat na Afrika gegaan het gedurende hierdie tydperk (Anon., 2007a:46). Internasionaal is bevind dat vertroue in openbare outoriteite aan die daal is. Die konsep van 'n "sosiale kontrak" bly 'n illusie. Tien jaar nadat Tony Blair in Brittanje belowe het dat die vertroue in politiek herstel sal word, is slegs een uit elke vyf mense van mening dat hyself te vertrou is. Die geloofwaardigheid van outoriteite het in feitlik elke area van die openbare lewe gedaal. Uit die internasionale data in die volgende tabel kan afgelei word dat slegs regters positiewe groei aangeteken het, veral omdat hulle teenoor (korrupte) politici optree (Anon., 2007b:41). 
Figuur 1: Outoriteite se geloofwaardigheid (Anon., 2007b:41)

Vir Suid-Afrika het die president 'n ondubbelsinnige waarskuwing uitgestuur oor die florerende onetiese praktyke wat in die openbare sektor tot gewelddadige protes oor swak openbare dienslewering en sosio-ekonomiese gebrek lei (Anon., 2005a:37). Die ANC as die regerende party, het toegegee dat die grootste uitdaging die oënskynlike situasie is van geen reëls en regulasies oor hoe lede voordeel uit die ekonomiese geleenthede wat hulle beleide ontsluit, mag put sonder om die party in onguns te bring as gevolg van onetiese gedrag nie. Hierdie situasie word skynbaar vererger deur 'n gebrek aan begrip vir die kernwaardes van die party (Xundu, 2007:12):

Of course the ANC does not exist in a vacuum. We exist in a society in which the culture of short cuts or 'beating the system' is endemic. Too often entrepreneurship is confused with adventurism of the pillaging sort.

Die Instituut vir Sekuriteitstudies (ISS) het aangedui dat indien SuidAfrika ernstig is om dié probleem die hoof te bied, moet transaksies tussen politici en korporatiewe amptenare gemonitor word. Veral sewe areas is geïdentifiseer wat aan eksploitasie blootgestel is (ISS, 2007; Louw-Carstens, 2007:8): 
- Die berugte wapentransaksie is nog nie afgehandel nie en onlangse ondersoeke in Londen dui daarop dat andere ook geïmpliseer word, bo en behalwe die voormalige adjunkpresident Jacob Zuma.

- Die Sokker-wêreldbekertoernooi: Die konstruksiesektor verteenwoordig wêreldwyd een van die mees korrupte ekonomiese sektore, en hulle is verantwoordelik vir die bou van die infrastruktuur vir die toernooi. Die kombinasie van kontrakteurs en die aanvanklike massiewe begroting van R15 biljoen (en steeds stygend), kan potensieel katastrofiese gevolge hê.

- Dienslewering: Dit is 'n fundamentele reg dat alle burgers toegang het tot basiese dienste. Die aantrekkingskrag van baie winsgewende tenders is egter groot en dus sal sommige van die politieke en ekonomiese elite aanhou om geld van die armes te steel. Een oplossing is om die duisende staatsdiensamptenare noukeurig te monitor vir besigheidsbelange buite die owerheidsfeer. Onlangs is berig oor 'n hoof van die Departement van Plaaslike Regering en Behuising wie se vrou die direkteur van 23 maatskappye is wat regeringstenders ontvang.

- Demokrasie inkorporeer: Totdat die privaatfinansiering van politieke partye nie voldoende gereguleer word nie, kan meer skandale (soos "Oilgate") verwag word, en sal die eie belange van korporatiewe skenkers op 'n ongesonde vlak bly. Geld koop politiek.

- Besigheid soos gewoonlik: Brett Kebble se grafskrif "'n groot Suid-Afrikaner" moedig ander aan om dié oneerlike kapitalis na te volg. Jare na die aanvaarding van die eerste King Kode van Korporatiewe Beheer is dit duidelik dat selfregulering nie die antwoord is nie. Die Wet op Korrupsie van 2004 is tot dusver swak toegepas - die register vir tenderoortreders is feitlik leeg, en daar is min vervolgings van maatskappye wat by omkopery betrokke was.

- Die Parlement: Sake soos die vorige hoofsweep se seksuele teistering- en die Travelgateskandaal, boesem nie juis vertroue in die Parlement as die hoogste toesighoudende institusie in nie. Die onlangse aankondiging van die beplanning van 'n R350 miljoen banketsaal vir die Parlement help nie juis om die toedrag van sake te verbeter nie. 'n Komitee is ook aangestel om aanbevelings te maak oor die verbetering van die institusie se integriteit. 
- Apartheidsbuit: Navorsing het ook grootskaalse korrupsie in die apartheidsera uitgewys, maar dit het tot niks gelei nie. Laasgenoemde gebrek aan strafloosheid moet voorkom word deur die betrokke gesagsliggame wat die verantwoordelikheid moet uitoefen om soortgelyke aktiwiteite uit te wys wanneer dit plaasvind.

\subsection{Oorsake}

Witboordjiemisdaad kan veral aan die volgende oorsake toegeskryf word (Camerer, 1996; Hogg, 2007):

- die verswakking van gemeenskappe se waardes en in die besonder die sake-etiek;

- ekonomiese druk (soos uitgerekte resessietoestande);

- 'n "word-gou-ryk"-etos, soos kriminele sindikaatgroepe wat in winsgewende produkte byvoorbeeld onwettige sigarette en roofkopieë DVD-rolprente spesialiseer, omdat die winsmarges baie groot is. Die wins op een kilogram onwettige DVD's is drie keer dié van kokaïne, met die boetes wat boonop relatief klein is;

- politieke onsekerheid soos wat in Suid-Afrika tans die geval is; en

- toenemende gesofistikeerde en georganiseerde misdaadsindikate wat ook die inligtingstegnologie eksploiteer.

Aartsbiskop Desmond Tutu het opgemerk dat Suid-Afrikaners hulle sin vir reg en verkeerd verloor het (Morgenrood, 2007:19). Witboordjiemisdade floreer in 'n sosiale- en besigheidsomgewing waarin lae etiese standaarde en morele fleksibiliteit heers. Individue oortree belangrike normatiewe en etiese standaarde, maar neutraliseer enige beskrywing van sodanige gedrag as afwykend of krimineel. Die neutralisering van etiese beperkings kan byvoorbeeld diefstal regverdig deur dit af te maak as om "slegs te leen" of "niemand word regtig in die proses beseer nie".

In teenstelling met lande in die Verenigde Koninkryk waar bevind is dat meer as $70 \%$ van oortreders werknemers is, het dieselfde resultate in Suid-Afrika aangedui dat die meerderheid bedrog deur die bestuur gepleeg word (Anon., 2007b:41). Vervolgens word gefokus op die agteruitgang van etiek in bestuursprogramme by een van die primêre opleiers van bestuurslui wêreldwyd, naamlik sakeskole. 


\section{Die agtenuitgang van sake-etiek}

Business schools have gotten off the hook, and they're still getting off the hook. For decades they haven't done nearly enough. They've marginalized [the teaching of business ethics] it. We need to put them under the microscope (Walzer, 2003).

Sedert die ontstaan van sakeskole word vrae gevra oor hulle bydrae - hetsy deur die sogenaamde "wetenskaplike"- (akademie) of "professionele"- (bestuurspraktyk) modelle. Die aanbeveling is gewoonlik dat 'n groter fokus geplaas word op die sogenaamde dissiplines met "harde" vaardighede. Sodanige aanbevelings word gewoonlik goed deur sakeskole ontvang wat daarna strewe om hulle aanvaarding in die akademiese gemeenskap te verbeter (Heskett, 2005). Laasgenoemde is 'n belangrike rede vir die neiging van 'n steeds groterwordende gaping tussen die milieu van die bestuurspraktyk (waarvoor MBA's en ander bestuurskursusse veronderstel is om voor te berei) en die wêreld van die akademie waarin sakeskoolpersoneel bevorder word. Die vraag kan dus tereg gevra word of sakeskole steeds relevant is in soverre gefokusde opleiding verskaf word. Na Watergate en die omkoopskandale van die sewentigerjare, is etiek veral as 'n noodsaaklike deel van bestuursprogramme beskou. Met die afgelope aantal jare se "bulmark" in sakeskandale wil dit voorkom asof die omgekeerde nou plaasvind: dit blyk dat etiek uitgefaseer of afgeskaal word! Dit gebeur terwyl die taak om etiese gedrag te beïnvloed ooglopend moeiliker as ooit vantevore is. Kelly (2005) som die situasie treffend op deur te sê:

It's a heckuva time to be dropping business ethics courses!

Wêreldwyd blyk dat in markterminologie 'n "beergedrewe" tendens in etiek op sakeskoolvlak bestaan. Hierdie beermarktendens word gewoonlik gekenmerk deur 'n omvangryke daling in die betrokke mark. Binne die konteks van die mark vir sake-etiekopleiding aan sakeskole is gevind dat met praktyke soos die afskaling, óf wanneer sake-etiekkursusse uit kurrikula verwyder word, 'n beermarkgedrewenheid heers (Kelly, 2005; Singer, 1987; Swanson, 2003; Trujillo \& Forde, 2002; Verschoor, 2003; Walzer, 2003). Indien dit met die misdaadsituasie op die meeste vlakke vergelyk word (wat in 'n langtermyn bulmarkfase is), word inderdaad 'n kontradiksie in terme ervaar. Dit is kommerwekkend dat die sogenaamde vermelde beermarkgedrewenheid gewoonlik gekenmerk word deur wydverspreide pessimisme. Dit het tot gevolg dat in afwagting op verdere dalings (verliese), die negatiewe sentiment in ' $n$ bose 
kringloop op homself teer. Verskeie redes word aangevoer vir bogenoemde korrosie in sake-etiekopleiding (De Russy \& Langbert, 2005; Kelly, 2005; Swanson, 2003; Verschoor, 2003; Walzer, 2003):

- Daar kan nie plek gevind word in die reeds oorvol sillabusse nie.

- Fakulteitslede verstaan dit nie óf sien nie die waarde daarvan in nie. Dit is waarskynlik ook 'n geval van onbevoegdheid om van hierdie kwessies te hanteer, soos die problematiese kwessie van "etiese relatiwiteit", naamlik dat omkopery standaardpraktyk in sommige lande is en in ander nie.

- Om verkeerde beweegredes, naamlik dat 'n akkrediteringsliggaam dit vereis: die AACSB (Association to Advance Collegiate Schools of Business) in St. Louis, het dit as akkrediteringstandaard vereis. Toe die vereistes later meer soepel geword het, is gevind dat sakeskole aanpassings ten koste van etiek gemaak het.

- Die etiekbelangegroep in fakulteite beskik oor té min stemkrag om dit te laat geld.

- Met die programstruktuur waarin keuses ingebou is, word gevind dat leerders ter wille van loopbaanvooruitsigte eerder die vakke met die "harde" vaardighede kies - 'n soort van "akademiese kapitalisme" waar onderrig verander in posopleiding.

- Min toegangsvlakposte in sake-etiek of korporatiewe sosiale verantwoordelikheid bestaan in die praktyk.

- Keusevakke skep die persepsie dat etiek buite die basiese sakefunksies val. Etiek is egter altyd belangriker as soepelheid. Laasgenoemde is in wese 'n skuiwergat waardeur etiek uit die kurrikulum kan wegraak.

- Die aanbieders van etiek word geëtiketteer as do-gooders en word selfs gemarginaliseer deur die res van die Fakulteit.

- Die persepsie bestaan dat etiek 'n negatiewe kontekstualisering het wat kan lei tot redelike siniese uitgangspunte soos die siening dat sake-etiek eerder 'n gier is wat weinig te doen het met die daaglikse realiteite soos om 'n sake-onderneming te bestuur. 'n Uitvloeisel hiervan is byvoorbeeld die feit dat die helfte van die Amerikaanse staat Virginia se 18 MBA-programme nie etiek aanbied nie. Hierdie soort gebrek aan fokus op etiek in hoër onderwysprogramme dra by tot skeptisisme oor die noodsaak daarvan. 
- Die standpunt bestaan dat etiek 'n persoonlike saak is omdat dit meer gaan oor religie as oor die bestuur van 'n sakeonderneming. Gevolglik is die "beste lyn van verdediging" nie sake-etiekopleiding aan sakeskole nie, maar eerder die vraag wat in die kerke, skole en by die huis gedoen word - dit is lank voordat daar by 'n bestuursopleidingsprogram soos die MBA uitgekom word.

- Die onsekerheid of etiekopleiding wel enige effek op sakeondernemings se winsmarges sal hê - die sogenaamde "bottomline" - is ook 'n faktor.

- Etiekopleiding het te veel temas om te dek - van verdienstemanipulering, geldwassery, prysvasstelling, rekeningkundige bedrog, diefstal van intellektuele eiendom, binnehandel, diskriminasie, seksuele en ander teistering, "verklikkers" (whistleblowers), tot die morele implikasies van besoedeling, of om 'n fabriek te sluit, en so meer. Dit word dus eerder heeltemal weggelaat.

- Daar is geen eksterne druk op dekane van fakulteite om aan etiek sy regmatige plek te besorg nie. Fakulteitslede kry geen "meriete" indien hulle etiese kwessies in lesings hanteer nie.

- Die langdurige aanvalle op die basis vir sedelike gedrag (morals) het 'n kultuur geskep wat die belangstelling in etiek belemmer. Dit blyk dat daar weinig fokus is op etiese deugde as 'n voorvereiste vir deelname aan die beskaafde wêreld.

- Filosofiese positivisme (wat aanvoer dat wetenskaplike kennis die enigste outentieke kennis is wat net deur middel van die wetenskaplike metodologie tot kennis ontsluit kan word en wat dus geen rol vir geloofsoortuigings in die wetenskap toelaat nie) en standpunte byvoorbeeld van die Nihiliste (wat onder andere aanvoer dat die menslike bestaan sonder objektiewe betekenis of noodsaaklike waarde is, soos Stanley Fish se antifoundationalism) is bydraende faktore tot die agteruitgang van sake-etiek in sillabusse. Ekonome word dikwels geblameer vir die weerstand teen die inkorporering van etiek in programme en die Neo-Klassieke ekonomiese paradigma word gesien om minagtend met etiek om te gaan.

- Korrosie van sake-etiekopleiding is ook as gevolg van die kontemporêre vergoeding- en bestuurspraktyke wat uit ekonomiese teorieë se beklemtoning van materiële insentiewe ontwikkel het. 
Die netto effek van bogenoemde is dat:

... over time - driven by the financial theory of the firm and careerism at its worst - has been a downward spiral in the quality of education, with more quantitative stuff, and far less emphasis on business being an institution of society whose final end is to serve the common good (AACSB, 2004).

\section{Die relevansie van etiek vir sakeskole}

The real question is how to be relevant. (Jeffrey Garten, Dean of the Yale School of Management, aangehaal deur Heskett, 2005.)

Die krisis in etiek (Swanson, 2003:1) word geïllustreer deur die wandade by die hedendaagse Enrons, World.Coms, Parmalats, Tylenols, Exxon Valdez'e, Volkswagens (Anon., 2005b:55), en so meer. Laasgenoemde skandale is ook getuienis dat 'n beduidende deel van die sakewêreld nog oortuig moet word dat etiek betaal. Gegewe dat alle dinge gelyk is (ceteris paribus), sal bestuurslede altyd die "hoë pad" kies, maar ongelukkig, behalwe in hipotetiese situasies, is alle ander dinge nooit gelyk nie (Cialdini et al., 2004:6768). Werknemers word in enige onderneming deur 'n legio faktore gemotiveer soos verkoopsyfers, die maatskappy se finansiële toestand, sake-oorlewing, mededingende kwessies en loopbaanbevordering. Hierdie aspekte blyk maklik voorrang te geniet bó hulle morele kompas. Soveel meer so, dat die persepsie bestaan dat onetiese gedrag soos omkopery in die markte vir motorkomponentverskaffers, sistemies van aard is en deel word van besigheidsbeleid (Anon., 2006). Nieteenstaande ooglopende bewyse van reuseboetes wat in die markplek vir swak etiese praktyke opgelê word, blyk dit moeilik te wees om akademici en praktisyns te oortuig dat goeie etiek ekonomies sowel as moreel geregverdig kan word en dus dat etiek betaal. ' $n$ Voorbeeld is die Mededingingtribunaal wat aan die Suid-Afrikaanse Lugdiens onlangs 'n boete van R45 miljoen opgelê het weens sy onmededingende optrede met aansporingskemas aan reisagente tot nadeel van ander mededingers (Visser, 2005:21).

Navorsing onder die top 30 sakeskole in die wêreld het bevind dat sake-etiek in bestuursprogramme grotendeels geïgnoreer word (Trujillo \& Forde, 2002). Indien sakeskole relevant wil bly, moet hulle op die aktuele verwikkelings en tendense in die dinamiese markomgewing in hulle programme fokus. $\mathrm{Na}$ bogenoemde skandale het veral sakeskole onder hewige kritiek deurgeloop en is 
hulle deels daarvoor geblameer (Anon., 2007a:71). Programme moet dus voortdurend fokus op praktykuitdagings (Verschoor, 2003); etiek moet derhalwe 'n impak hê op bes/uitneming (De Russy \& Langbert, 2005). Sakekwessies soos oornames en samesmeltings waar daar botsende belange kan wees en die ontvang van geskenke (etes of vliegkaartjies) is nie swart-en-wit sake nie, maar eerder skakerings van grys (Singer, 1987). Die klein grysareabesluite kan uiteindelik lei tot meer ernstige etiese- en wetlike oortredings (Flat Rock, 2005).

Die feit is dat die toonaangewende maatskappye meer aggressief MBA-graduandi werf en hulle in belangrike besluitnemingsposte plaas. Etiek kan egter 'n betekenislose begrip word indien daar nie 'n objektiewe "reg" en "verkeerd" bestaan nie (De Russy \& Langbert, 2005). Sensitisering oor die etiese impak van besluite moet kontinu plaasvind. In 'n opname onder 1700 MBA-studente is byvoorbeeld bevind dat $20 \%$ oortuig voel dat hulle nie voorberei word op besluitneming wat in konflik gaan wees met hulle persoonlike waardes nie (Verschoor, 2003).

'n Probleem wat ook manifesteer is dat leerders wat weinig etiek geleer het gevolglik in die markplekke min kennis dra van die talle potensiële etiese problematiek. Die wandade by die Enrons van die wêreld kan nie totaal geïsoleer word van besluitnemingsprosesse deur die top MBA-graduandi's van die afgelope jare nie. In hierdie verband is dit belangrik dat in die aanbied van etiese kwessies, die punt gemaak moet word dat dit in wese neerkom op strategiese- en risikobestuurskwessies vir ondernemings (Klusmann, 2005).

Sakeskole het 'n verantwoordelikheid om positiewe etiese gedrag te beïnvloed (Singer, 1987). Net soos geeneen deur 'n onetiese regspersoon verteenwoordig wil word nie, moet dieselfde logika ook van toepassing wees op die toekomstige bestuurskorps wat met gemeenskappe se skaars hulpbronne toevertrou word. In hierdie verband wys De Russy en Langbert (2005) daarop dat die Enronskandaal duidelike raakvlakke met die akademie gehad het: Kenneth Lay (Enron se voormalige voorsitter) het 'n Ph.D. in ekonomie van die Universiteit van Houston gehaal en Jeff Skilling (voormalige Hoof Uitvoerende Amptenaar) is 'n Harvard MBAgegradueerde.

\subsection{Die nuwe ekonomie}

Die sogenaamde "nuwe ekonomie" het drie onderskeidende kenmerke (Kelly, 1998:2), naamlik dat dit globaal ten gunste is van 
ontasbare dinge soos idees, inligting en verwantskappe, en ook dat dit aanmekaargeskakel is. Markte funksioneer nou 24 uur van die dag en 'n gebeurtenis in 'n sekere land kan baie gou die investeringsmarkte elders beïnvloed. In hierdie netwerkekonomie het die mens te doen met magtige tegnologiese- en steeds innoverende kommunikasieverwikkelings (Sunter, 1999:5). Binne die konteks van dinamiese markte is die gevolg dat nuwe geleenthede te voorskyn kom sodat diegene wat volgens die nuwe spelreëls funksioneer, welvarender kan word. Hierdie nuwe spelreëls wat basies in die nuwe ekonomie tegnologiegedrewe is, het gevolglik die drywer van groeigeleenthede geword. Só het vervaardigde goedere in die VSA die weg gebaan vir die nuwe inligtingsgebaseerde sektor wat reeds meer as $15 \%$ van die totale VSA se ekonomie beslaan. Die Microsoft-korporasie, wat prominent is as multinasionale maatskappy in die nuwe kennisekonomie, is gevolglik die hedendaagse rolmodel vir die markplek en nie meer byvoorbeeld 'n General Motors nie. Derhalwe volg dit dat kommunikasie, wat die basis vorm van gemeenskappe, die eie individuele identiteit en van alle ekonomiese stelsels, nou die ekonomie is - dus 'n netwerkekonomie.

Dit is ook nie toevallig nie dat globale netwerke te voorskyn gekom het ongeveer op dieselfde tyd as die Postmoderne beweging (Kelly, 1998:159). In postmodernisme bestaan daar 'n gebrek aan 'n duidelike sentrale hiërargie en 'n universele dogmatiek, asook geen grondslagliggende etiek nie. Sowel die postmodernisme as die netwerkbedryf verander resultate in fragmentasie, onstabiliteit en onsekerheid. Netwerkbeginsels doen afstand van rigiditeit, geslote strukture, universele skemas, sentrale outoriteit en vaste waardes. Sunter (1999:31) verwys ook na 'n bedreiging in hierdie konteks, naamlik dat die nuwer generasie meer individualisties is, met as uitvloeisel hiervan dat hulle meer selfvertroue het om hulle eie belange te volg. Laasgenoemde is ontvanklik vir ontwrigting, vir die verspreiding van netwerkgebaseerde misdaad en vir die bevordering van 'n gebrek aan waardes.

Omdat die aard van die netwerkekonomie disekwilibrium, fragmentasie, onsekerheid en relativisme skep, is die ankers van betekenis en waardes skaars. In die afwesigheid van betekenis en die gebrek aan waardes, word die tegnologie op sigself die antwoord wat ook gemeenskappe vorm en besluite vir die mens neem. In die afwesigheid van standvastige oortuigings laat die mens toe dat tegnologie die rigting stuur. Dit beïnvloed uiteindelik alle menslike interaksies - veral belangrike aspekte vir die sin van die 
lewe soos liefde, gesinslewe, kultuur, gesondheid, spiritualiteit en die omgewing (McKeever, 2000:1).

\subsection{Die amorele sakemilieu}

There seems to be a popular view that one has to be amoral to succeed in business (Singer, 1987).

Voortspruitend uit die institusionele korrosie van etiek by sakeskole, wil dit voorkom of die fokus is om by studente die konteks van 'n normatiewe amorele houding te kweek wat onetiese praktyke in die markplek verdra (Kelly, 2005). Mamaila (2005:18) verwys na die morele verval wat wyd in die ekonomie plaasvind:

... die drempel van moraliteit is so verlaag dat enigiemand wat probeer aandring op hoër standaarde gevaar loop om hom die woede van beleidmakers ... op die hals te haal.

Mediaberigte oor bedrog en korrupsie in alle vlakke van die bestuur van die volkshuishouding, nie-regeringsorganisasies en ongekende gulsigheid in die privaatsektor oorspoel die hedendaagse SuidAfrika, waar dit "lyk of gierigheid soos 'n virus versprei". Die skadukant van hierdie tipiese MBA-kultuur is die houding wat impliseer dat reëls gebuig kan word (Flat Rock, 2005). Die regte oriëntering kan dalk bewerkstellig word deur 'n ander siening oor etiek: op bestuursvlak (en dus MBA-opleiding) gaan dit wesenlik oor besluitneming, en etiek is ook besluitneming! In die onlangse sakeskandale word tipies 'n persoon aangetref met 'n groot mate van outonomiteit in 'n multi-nasionale onderneming met gesentraliseerde inligtingstelsels - "the damage you can do under those circumstances is considerable" (Godfrey, 2004).

Enersyds sluit die kontemporêre amorele ekonomie slegs goedere in wat met monetêre pryse in die markplek verhandel word, teenoor 'n morele ekonomiese beleid, andersyds, wat waardes promoveer, maar wat egter weens die oënskynlike gebrek aan monetêre pryse daaraan nie deel uitmaak van hierdie handelstelsel nie. Met ander woorde: wat is die markwaarde verbonde aan byvoorbeeld integriteit in die praktyk? Dit kan derhalwe ook as 'n sakeskool se verantwoordelikheid beskou word om die bestuurskorps in die markplek te help transformeer, sodat waardes, alhoewel nie "monetêr geprys" nie, nie onderhandelbaar mag wees nie.

Die kritiek op etiekaanbiedings in die kontemporêre benadering is verder gerig op die "koste-regverdigende" oriëntasie waar besprekings fokus op die opbrengskoers, koste-voordele, die netto 
heersende waarde, ensovoorts (Kellogg School of Management, 2002). 'n Opname onder meer as 500 MBA-kandidate het getoon dat meer as $80 \%$ van die eerstejaars die "maksimering van aandeelhouerswelvaart" as die vernaamste verantwoordelikheid van 'n maatskappy aangedui het (Feuerherd, 2005). Hoe verder hulle studies vorder, word oorwegings soos gemeenskapsdiens, behandeling van werkers, omgewingsbeleide en so meer, al hoe minder belangrik.

Maatskappye soos die vroeër vermelde SAL, wat onbetaamlike, mededingende praktyke volg om korttermynwinste te verhoog, kan vind dat hierdie oortredings sosio-psigologiese reaksies ontketen wat uiteindelik 'n skadelik effek op fiskale uitkomste het (wat die korttermynwinste kan uitwis) (Cialdini et al., 2004:67). Ondernemings wat gereeld onetiese gedrag aanvaar, sal mettertyd interne konsekwensies ervaar wat skadelik vir die onderneming self sal wees. Dit is ook moeilik opspoorbaar, via die tipiese rekeningkundige metodes, as die ware oorsaak vir swak produktiwiteit en wanfunksionering.

Opleidingsprogramme wat nie gebaseer word op morele waardes soos vertroue, naasteliefde, eerlikheid, verdraagsaamheid, vergifnis en genade nie, is ongebalanseerd. Volgens Sunter (1999:11) sal suksesvolle maatskappye in die toekoms 'n gerigte fokus op etiek sowel as op wins moet hê. Die probleem kan onder andere gesoek word in die dilemma dat die sake-omgewing basies ' $n$ ambivalente verwantskap met die meeste deugde het. Die vryemark sê dat die strewe na die gemeenskaplike goedheid (common good) slegs bevorder word indien die koper en die verkoper elk in hulle eiebelang optree. Daar bestaan egter legio voorbeelde waar eiebelang gelei het tot eksploitasie in die markplek.

Die meerderheid werkende volwassenes funksioneer op die konvensionele vlak van kognitiewe morele ontwikkeling, wat impliseer dat hulle na buite fokus - primêr op hulle eweknieë en leiers vir riglyne in etiese dilemmas (AACSB, 2004). Die boodskappe wat bestuur stuur en die kontekste wat hulle skep is potensieel die grootste motivering vir etiese gedrag in besighede. Daarom rus daar 'n professionele verantwoordelikheid op sakeskole om ten minste by studente 'n etiese bewustheid te kweek (Kelly, 2005).

In 2005 het Lotriet 'n opname onder meer as 70 fase-een MBAstudente gedoen wat almal in bestuurshoedanighede by hulle werksplekke in Suid-Afrika funksioneer. In 'n oop vraag oor hulle 
verwagtings (sien Figuur 2) ten opsigte van hulle MBA-kwalifikasie het slegs $1 \%$ van die respondente onderskeidelik aangevoer dat hulle 'n goeie rolmodel vir ondergeskiktes wil wees en ook sodoende regverdigheid wil uitoefen. Slegs 3\% het aangedui dat hulle in die proses 'n beter persoon wil word. Die meerderheid het klem gelê op bestuursbevoegdhede (92\%), vergoedingspakkette $(30 \%)$, en leierskapsvaardighede (24\%) wat almal regstreeks verband hou met maatskappye se winsmarges (die sogenaamde bottom-line). Die vraag na "sagte vaardighede" was nie vir hulle ter sprake nie. Die vernaamste respons in hierdie verband was soos volg:

Figuur 2: MBA-kwalifikasieverwagtings (Lotriet, 2005)

Hierdie opname bevestig die belangrikheid van 'n breër fokus deur 'n sakeskool as om net 'n finansiële rekeningkundige belang te hê by die bottom line van 'n korttermynwins of -verlies. Net die sosioekonomiese behoeftes van die onmiddellike markomgewing behoort dit duidelik te maak. Alhoewel die studie hoofsaaklik gefokus het op die internasionale tendens met betrekking tot sake-etiek, is SuidAfrikaanse werkgewers en MBA-graduandi dit eens oor die volgende:

MBA schools are doing a lousy job of teaching business ethics (these) ...! (Furlonger, 2006:36). 


\section{Gevolgtrekking}

In die breë moet die etiese klimaat in Suid-Afrika verander word, maar nie bloot as 'n "openbare betrekkinge"-oefening vir die heersende regerende party nie. Die eerste stap vir 'n oplossing van Suid-Afrika se misdaadproblematiek oor die algemeen is om verby die ontkenningstadium te beweeg. Misdaad is daarvoor verantwoordelik dat Suid-Afrika se ekonomiese kostes besig is om te eskaleer, en die onmiddellike uitdaging vir die staat is om bronne te mobiliseer om witboordjiemisdaad méér gevaarlik en minder winsgewend te maak. Gegewe die antitese wat bestaan ten opsigte van die heersende opwaartse marktendens in witboordjiemisdaad en die dalende marktendens in sake-etiekskoling, is die geleentheid om etiekopleiding op te gradeer gevolglik by 'n kritieke tydstip. Sakeetiek verdien 'n plek as 'n legitieme bestuurskwessie, en etiese kapasiteit móet in die markplek geskep word. In hierdie verband word aanbeveel dat omvattende sake-etiekopleiding aan alle tersiêre instellings in die land as deel van die volgende akkrediteringsproses deur die Hoër Onderwys Kwaliteitsraad (HEQC) verpligtend gemaak moet word. Sakeskole het hier 'n besondere rol om te vervul. Laasgenoemde sal 'n bydrae lewer om ook etiese standaarde te verbeter.

Sakeskole wat by uitstek gefokus is op bestuursopleiding, moet die voortou neem en nie hulle verantwoordelikheid in hierdie verband versaak nie. Uit die navorsing kan afgelei word dat etiekopleiding in sakeskole tans nie die prominensie kry wat dit verdien nie. Etiek kry oor die algemeen goeie lippediens, maar dit is nie naastenby voldoende brongebaseerd nie. Etiek vir sakeskole sal altyd relevant wees, want daar bestaan gedragsimperatiewe wat belangrik bly, selfs in die afwesigheid van filosofiese regverdiging. Die karakter van sakeskole oor die algemeen getuig van 'n tipiese positivisme en logiese positivisme wat wetenskapsbeoefening laat seëvier, waarin norme en waardes nie 'n plek verdien nie. Waar wel aandag gegee word aan 'n geïntegreerde etiek in sommige modules, geskied dit vanuit 'n verkeerde neo-kapitalistiese/ekonomiese benadering.

Bogenoemde is slegs enkele aspekte wat die persepsie onderskryf van ' $n$ hedendaagse krisis in die etiekopleiding van bestuurslui, maar dit bied uitdagings wat sakeskole moet aangryp om steeds dinamies, relevant en waardetoevoegend te wees. Die eis om rentmeesterskap is ook vir die adres van sakeskole wat primêr gefokus is op die bestuursopleiding van diegene wat reeds in die arbeidsmarke werksaam is. Dit plaas ook 'n bepaalde aanspreeklikheid op sakeskole om die verantwoordelikhede in hierdie 
verband na te kom. Die roeping as rentmeester verg om as sodanig die gebruiksreg van God se besittings met dankbaarheid te aanvaar en met selfbeheersing te gebruik, maar indien die omgewingskrisisse van die dag in ag geneem word, is hierdie slegs een voorbeeld van die versaking van die rentmeesterskapsbeginsel. Sakeskole moet ook verantwoordelikheid aanvaar om 'n sakekultuur te help skep waarin organisasies hulle stellinginname in die gemeenskap deur middel van 'n etiese kode behoort te verklaar. In hierdie verband moet sakeskole elkeen 'n openbare verklaring maak oor hulle voorgenome optrede in die verwesenliking van hulle missie en doelstellings, sodat hulle verantwoordelikhede in die opleiding van sakelui en bestuurders duidelik blyk. Laasgenoemde benodig egter ook ondersteuningsbasisse soos akkrediteringsliggame (byvoorbeeld die Hoër Onderwys Kwaliteitsraad). 'n Interne kampioen moet voorts aangewys word wat die hindernisse van fakulteitspolitiek en eie gevestigde belange kan behandel sodat etiek tot sy regmatige posisie in sillabusse geaktiveer kan word. Etiek op sakeskoolvlak verg dringend 'n meer gefokusde benadering tot die uitdagings van die problematiek in die markplek - dit sal ook hier morele waagmoed vereis.

\section{Geraadpleegde bronne}

AACSB

see ASSOCIATION TO ADVANCE COLLEGIATE SCHOOLS OF BUSINESS

ANON. 2005a. The president hits out at corruption. The Economist: 37, 18 Jun.

ANON. 2005b. German business: dark days for Volkswagen. The Economist: 55-56, 16-22 Jul.

ANON. 2006. Dogmeat and the truffle pig. The Economist: 7 Sept. http://www.economist.com/business/displaystory.cfm?story_id=7887902 Date of access: 6 May 2007.

ANON. 2007a. Big men, big fraud and big trouble. The Economist: 45-48, 28 Apr.

ANON. 2007b. Public attitudes - trust me, I'm a judge. The Economist: 41, 5 May.

ASSOCIATION TO ADVANCE COLLEGIATE SCHOOLS OF BUSINESS. 2004. Ethics education in business schools: report of The Association to Advance Collegiate Schools of Business (AACSB) to the International Board of Directors. http://www. aascsb.edu Date of access: 10 Apr. 2007.

BOTHA, R. 2007. Raak van die struikelblokke ontslae. Beeld-Sake24: 11, 11 April.

CAMERER, L. 1996. White-collar crime in South Africa: a comparative perspective. http://www.iss.co.za/Pubs/ASR/5No2/5No2/WhiteCollarcrime.html Date of access: 10 Mar. 2007.

CIALDINI, R.B., PETROVA, P.K. \& GOLDSTEIN, J.N. 2004. The hidden costs of organisational dishonesty. MIT sloan management review, 45(3):67-73. 
CRANSTON, S. 2006. Is fraud under control? Financial mail: 57, 13 Oct.

DE RUSSY, C. \& LANGBERT, M. 2005. The corrosion of ethics in higher education. http://www.insidehighered.com/views/2005/07/05/derussy Date of access: 5 Jul. 2005.

FEUERHERD, J. 2005. Ethics education grows in importance for MBA candidates. http://www.natcath.com/NCR_Online/archives/102502/102502w. htm Date of access: 26 Jul. 2005.

FLAT ROCK. 2005. Inmates teach MBA students ethics from behind bars. http://flatrock.org.nz/topics/prisons/inmates_teach_mba_students_ethics. htm Date of access: 26 Jul. 2005.

FURLONGER, D. 2006. Ranking the MBA's - get real. Financial mail: 34-53, 13 Oct.

GODFREY, P.C. 2004. Business ethics and professional conduct. Winter. http://marriotschool.byu.edu/servicelearning/mba604.cfm Date of access: 26 Jul. 2005.

HARTLEY, W. 2007. State bonanza for private security. Business day: 3, 12 Jun.

HESKETT, J. 2005. How can business schools be made more relevant. www.http://hbswk.hbs.edu/item.jhtml?id=4886\&t=heskett\&oid=4886\&rid=1\&hid=-1\&aid=-1 Date of access: 11 Jul. 2005.

HOGG, A. 2007. Criminal tentacles sucking SA. http://www.moneyweb.co.za/ $\mathrm{mw} / \mathrm{view} / \mathrm{mw} / \mathrm{en} /$ page32979?oid=61533\&sn=Detail Date of access: 10 Apr. 2007.

HONEY, P. 2006. Dazed by direct hits. Financial mail: 90-91, 13 Oct.

INSTITUTE FOR SECURITY STUDIES. 2007. South Africa: another great year for corruption. http:www.issafrica. org/index.php?link_id Date of access: 29 May 2007.

ISS

see INSTITUTE FOR SECURITY STUDIES

KELLOG SCHOOL OF MANAGEMENT. 2002. Is education the answer on ethics? http://www.businessweek.com/bschools/content/jul2002/bs 2002078_9726.htm Date of access: 14 Jan. 2008.

KELLY, K. 1998. New rules for the new economy. New York: Penguin.

KELLY, M. 2005. It's a heckuva time to be dropping business ethics courses. http://www.business-ethics.com/whats_new/bestbizschools.html Date of access: 26 Jul. 2005.

KLUSMANN, T. 2005. MBA - making business accountable. http://www. business-ethics.com/whats_new/bestbizschools.html Date of access: 26 Jul. 2005.

LOTRIET, R.A. 2005. Kwalifikasieverwagtings van MBA-studente. (Jaarlikse opname onder MBA-Fase 1 studente wat op die Vanderbijlpark en Potchefstroomkampusse van die Noordwes-Universiteit geregistreer is.)

LOUW-CARSTENS, M. 2007. Hoë se vrou kry glo staatstenders. Beeld: 8, 30 Mei.

MALALA, J. 2006. Fishy business. Financial mail: 109, 13 Oct.

MAMAILA, K. 2005. Die morele verval moet gekeer word. Rapport: 18, 7 Aug.

McKEEVER, M.P. 2000. Moral economics - essays of economic theory to the moral perspective in poverty and development: an inter-faith perspective. http://www.mkeever.com Date of access: 10 Apr. 2007.

MORGENROOD, W. 2007. So glo Suid-Afrika. Rapport: 19, 20 Mei. 


\section{SARB}

kyk SUID-AFRIKAANSE RESERWE BANK

SINGER, A. 1987. The ethical education of an MBA. http://www.singerpubs. com/ethikos/html/mbas.html Date of access: 26 Jul. 2005.

SUID-AFRIKAANSE RESERWE BANK. 2007. Kwartaalblad van die SuidAfrikaanse Reserwebank, 243. Maart. www.reservebank.co.za/quarterly bulletin Datum van gebruik: 29 Mei 2007.

SUNTER, C. 1999. The winning business in the 21st century. Bylaag in Succeed SA. Parkhurst.

SWANSON, D. 2003. Business education puts corporate reputations at risk. November. http://64.233.161.104/search?q=cache:QfAv3_Maks8J:www. cba.k-state.edu/departments/ethics/docs/c. Date of access: 26 Jul. 2005.

TRUJILLO, V.A. \& FORDE, M. 2002. Is education the answer on ethics? July 8. http://www.businessweek.com/bschools/content/jul2002/bs2002078_9726. htm Date of access: 26 Jul. 2005.

UECKERMANN, H. 2007. Oppas vir base en "soet" klase. Sake-Rapport: 1, 22 Apr.

VERSCHOOR, C.C. 2003. Is ethics education of future business leaders adequate? http://ecampus.bentley.edu/dept/cbe/research/surveys_1.html Date of access: 26 Jul. 2005.

VISSER, A. 2005. SAL kry weer smoelhou. Sake-Beeld: 21, 29 Jul.

WALZER, P. 2003. Virginia MBA programs split on question of ethics. August 25. http://home.hamptonroads.com/stories/story.cfm?story=58792\&ran= 191793 Date of access: 26 Jul. 2005.

XUNDU, X. 2007. ANC in bid to clean up its act on ethical issues. Sunday times: 12, 25 Mar.

\section{Kernbegrippe:}

sake-etiek

sakeskole

witboordjiemisdaad

\section{Key concepts:}

business ethics

business schools

white-collar crime 


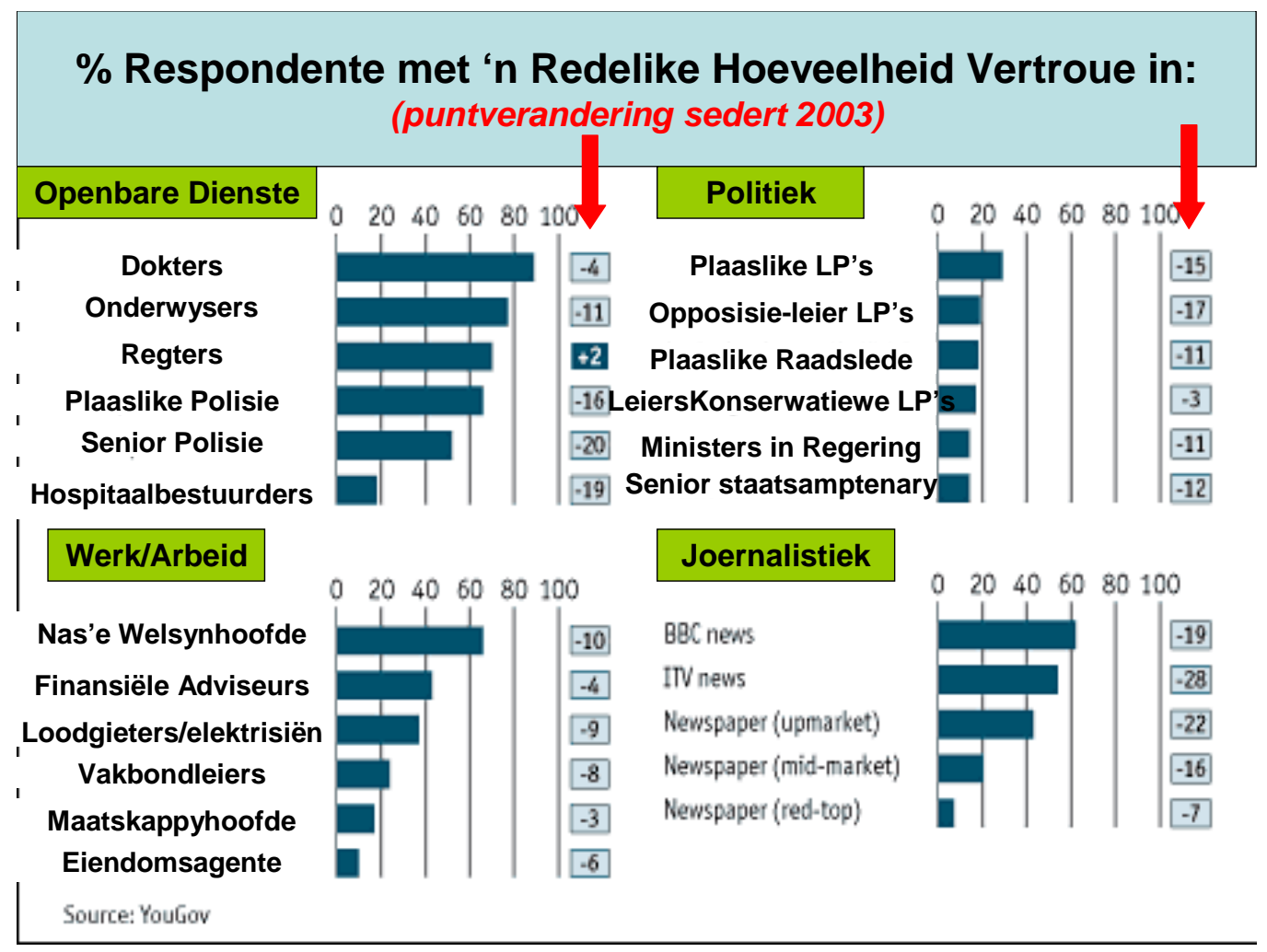




\section{MBA 2005-Verwagtings}

Persentasie

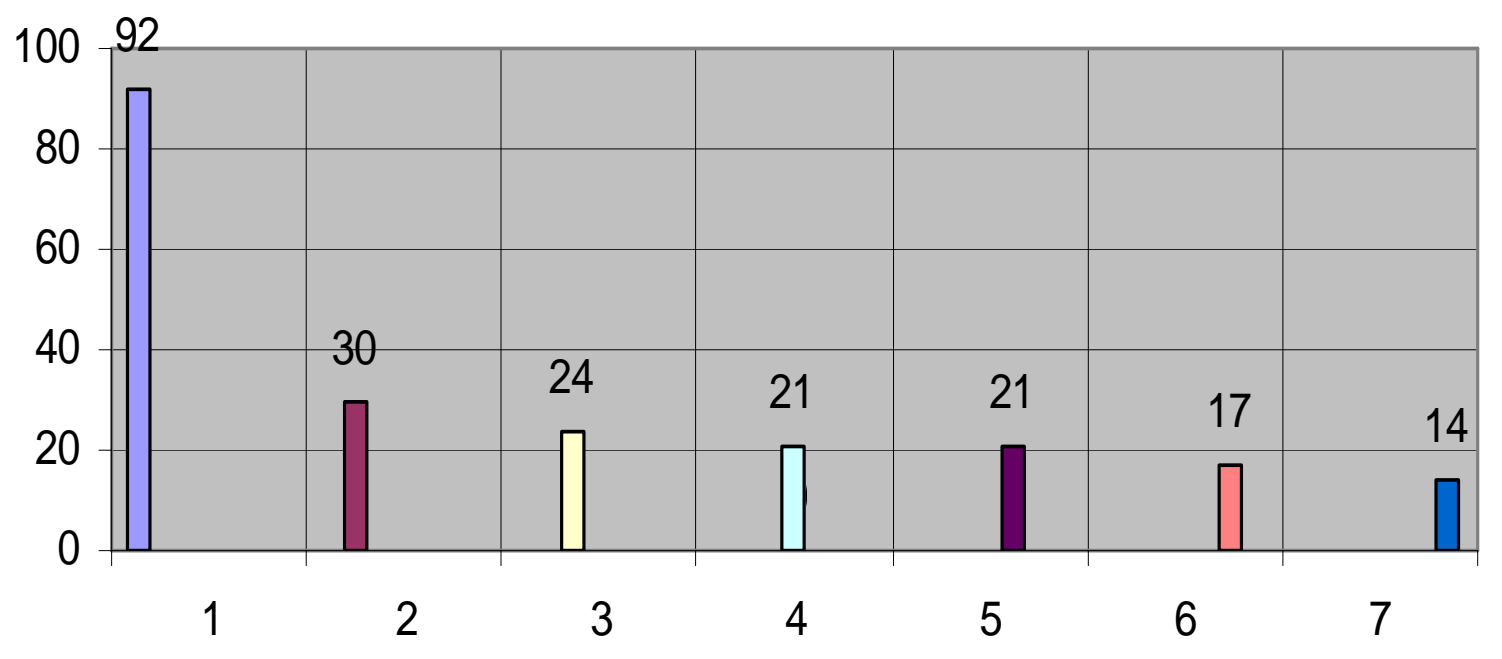

$\square 1$ Bestuur $\quad \square 2$ Verdienste $\square 3$ Leierskap $\square$ 4LoopbaanOnt

$\square 5$ Pers. Groei $\square 6$ Breër Uitkyk $\square 7$ Kennistoepassing 